\title{
Membrane vesicles shed by oligodendroglioma cells induce neuronal apoptosis
}

\author{
STEFANIA D'AGOSTINO ${ }^{1}$, MONICA SALAMONE ${ }^{1}$, ITALIA DI LIEGRO ${ }^{2}$ and M. LETIZIA VITTORELLI ${ }^{1}$ \\ ${ }^{1}$ Dipartimento di Biologia Cellulare e dello Sviluppo, Università di Palermo, Viale delle Scienze 16, I-90128 Palermo; \\ ${ }^{2}$ Dipartimento di Scienze Biochimiche, Università di Palermo, Via del Vespro 129, I-90127 Palermo, Italy
}

Received March 8, 2006; Accepted April 10, 2006

\begin{abstract}
In order to investigate the mechanism by which oligodendrogliomas cause neuronal damage, media conditioned by $\mathrm{G} 26 / 24$ oligodendroglioma cells, were fractionated into shed vesicles and vesicle-free supernatants, and added to primary cultures of rat fetal cortical neurons. After one night treatment with vesicles, a reproducible, dose-dependent, inhibitory effect on neurite outgrowth was already induced and, after 48-72 h of incubation, neuronal apoptosis was evident. Vesicle-free supernatants and vesicles shed by NIH-3T3 cells had no inhibitory effects on neurons. Western blot analyses showed that treated neurons expressed a decreased amount of neurofilament (NF), growth-associated protein (GAP-43) and microtubule-associated protein (MAP-2). Moreover procaspase- 3 and -8 were activated while $\mathrm{Bcl}-2$ expression was reduced. Vesicles were found positive for the proapoptotic molecule, Fas-ligand (Fas-L), and for the B isoform of Nogo protein, a myelin component with inhibitory effects on neurons. Nogo B involvement in the vesicle effects was analyzed both by testing the neutralizing capability of anti-Nogo antibodies and by removing the Nogo receptor from neurons by phospholipase $\mathrm{C}$ digestion. These treatments did not revert the vesicle effects. To test the role of Fas-L, vesicles were treated with functional anti-Fas-L monoclonals. Vesicle inhibitory and proapoptotic effects were reduced. Vesicles shed by ovarian carcinoma cells (OvCa), which are known to vehicle biologically active Fas-L, had similar effects on neurons to those of oligodendroglioma vesicles, and their inhibitory effects were also reduced by anti Fas-L antibodies. We therefore conclude that vesicles shed by G26/24 cells induce neuronal apoptosis at least partially by a Fas-L mediated mechanism.
\end{abstract}

Correspondence to: Dr M. Letizia Vittorelli, Dipartimento di Biologia Cellulare e dello Sviluppo, Università di Palermo, Viale delle Scienze 16, I-90128 Palermo, Italy

E-mail: mlvitt@unipa.it

Key words: oligodendroglioma, membrane vesicles, neuronal apoptosis, Fas-L, Nogo

\section{Introduction}

Oligodendrogliomas are considered as benign brain tumors for their slow growth rate but are biologically 'malign' due to the difficulty of surgically resecting them and for their ability to invade normal nervous tissue. The expansive growth of these brain tumors causes a rise in intracranial pressure, neuronal damage, and seizure (such as chronic epilepsy), which are frequent causes of patient death (1-6). Glioma demonstrate numerous effects on the surrounding non-tumoral tissue; in particular, on the peritumoral neurons where weak expression of Bcl-2 and bax suggests that apoptosis-related proteins might be expressed in peritumoral neurons but the underlying basic mechanism that leads to seizure is not understood $(6,7)$.

We investigated the possibility that neuronal damage could be actively induced by tumor cells and not only caused by constriction related to the increasing dimensions of the growing tumor.

Growth and survival of neuronal cells is highly influenced by the microenvironment being supported by the presence of neurotrophins and inhibited by factors released in the extracellular matrix by oligodendrocytes and perhaps by other surrounding cells (8).

As oligodendrocytes are known to inhibit both axonal elongation and neuronal regeneration, we supposed that oligodendroglioma cells could also have an inhibitory effect on neurons (9-12). Oligodendrocyte inhibitory effects are generally attributed to myelin membrane components including myelin-associated glycoprotein (MAG), the Nogo proteins and oligodendrocyte-myelin glycoprotein (Omgp) (13). The inhibitory action of all these proteins, on neurons, is reported to be mediated by interaction with the same membrane receptor: Nogo receptor (NgR), a glycosyl phosphatidyl-inositol (GPI)anchored membrane protein $(14,15)$. NgR is reported to interact with the neurotrophin receptor, $\mathrm{p} 75^{\mathrm{NTR}}$, which mediates signal transduction (16). NgR forms, with $\mathrm{p} 75^{\mathrm{NTR}}$ and Lingo-1, a functional complex that mediates the neurite growth inhibitory effects of its ligand by modulating the activity of Rho GTPases (17). Recent reports, however, indicate that Nogo protein signaling can be transduced also through other pathways. In some instances, $\mathrm{NgR}$ signal transduction was shown to be mediated by its association with Troy, an orphan member of the TNF receptor family and, in other instances, it was reported that Nogo-66 can act on neurons by interacting with receptors different to $\mathrm{NgR}(18-20)$. 
MAG, a member of the sialic acid-dependent immunoglobulin-like lectin (SIGLEC) family, was identified as the first myelin-derived growth inhibitory protein by two distinct groups $(21,22)$. It is a bifunctional protein that inhibits regrowth of adult axons, while stimulating axon growth from young neurons (23). Moreover, dMAG, a soluble proteolytic product of MAG, which is released from isolated or damaged myelin, also potently inhibits neurite outgrowth (24).

Nogo, identified independently by three groups, was found to have three different splice variants: Nogo A, Nogo $\mathrm{B}$ and Nogo $\mathrm{C}$ sharing a common C-terminal region which is homologous to a family of proteins called reticulons (25-27). Nogo proteins are known to be present both in the plasma membrane and endoplasmic reticulum (28). The Nogo A inhibitory effect on nerve outgrowth was reported to be due to the presence of two distinct domains: Nogo-66 and amino Nogo (or NiG). Nogo B and Nogo C isoforms share the Nogo-66 domain but lack amino Nogo. Nogo $\mathrm{C}$ is the smallest isoform and consists more or less exclusively of the Nogo-66 domain $(25,27)$. Transgenic mice expressing Nogo- $\mathrm{C}$ in peripheral Schwann cells, show delayed peripheral nerve regeneration (29). In Nogo B, the Nogo-66 domain is directly bound to the amino-terminal sequence of 172 amino acids also found in Nogo A (30). The ectopic expression of Nogo B in some tumor cell lines leads to growth inhibition and apoptosis (31).

OMgp was the latest myelin associated inhibitor of axonal growth to be identified in adult CNS $(32,33)$. It is a GPIanchored protein which inhibits neurite outgrowth and proliferation of cultured neurons (34).

All oligodendrocyte proteins identified so far for their inhibitory effect on neurons, are membrane components. The inhibitory effect of oligodendrocytes is, however, observed at several cell diameters distance and also when direct contact between oligodendrocytes and neurons is prevented $(11,35)$. For these reasons, we considered the hypothesis that oligodendrocytes and oligodendroglioma cells could shed membrane vesicles and that these vesicles could exert an inhibitory effect on neurons.

Membrane vesicles originate from the plasma membrane through a mechanism morphologically similar to that of virus budding. The vesicles are relatively large and heterogeneous in size; their diameters ranging from $\sim 100$ to $>1000 \mathrm{~nm}(36,37)$. Vesicle shedding is an active process that requires RNA and protein synthesis and occurs in viable cells with no signs of apoptosis or necrosis $(38,39)$. Although vesicle membranes carry most of the surface antigens expressed on the cell membrane, they originate from domains of the plasma membrane selectively enriched in membrane components including HLA class I molecules, $\beta 1$ integrin and membranebound MMP-9 (40,41).

Vesicle shedding was generally observed in tumor cells but vesicles are also shed by several non-tumor cells $(42,43)$. In normal cells, they have been reported to vehicle a variety of regulatory factors such as lectin 14 , membrane-bound burstpromoting activity, human macrophage colony-stimulating factor, TGFß and interleukin- $\beta$ (44-48).

Vesicle shedding was shown to be involved in cell migration and in tumor progression, a function that may be partially mediated by vesicle-bound proteinases $(37,41,49-52)$. Vesicles, however, are also enriched in phosphatidyl-serine and bind annexin $\mathrm{V}$; they could, therefore, exert a procoagulant effect $(39,43,48)$.

Vesicles shed by tumor cells were also shown to carry proangiogenic factors such as FGF-2, and to vehicle EMMPRIN, a transmembrane glycoprotein able to stimulate production of matrix metalloproteinases in surrounding fibroblasts $(39,53)$.

Shedding of membrane-associated molecules helps tumor cells to escape from induced apoptosis. For instance, TGFß present in vesicles shed by breast carcinoma is not only a proangiogenic factor but also a very potent immunosuppressor cytokine (40). Since antitumor lymphocytes interact with vesicles which are rich in HLA molecules and carry tumorassociated antigens, anti-tumor lymphocytes would be inhibited by shed vesicles $(40,41)$.

Vesicles shed by human colorectal carcinoma cell lines were found to carry biologically active Fas antigen. Shedding of the Fas antigen is likely to decrease the susceptibility of tumor cells to Fas-L induced apoptosis: Fas-bearing vesicles are in fact capable of interacting with Fas-L efficiently, thus neutralizing its ability to induce apoptosis (54).

On the other hand, Fas-L was present in vesicles shed by an activated human $\mathrm{T}$-cell line and in vesicles shed by ovarian carcinoma and by melanoma cells; Fas-L-bearing vesicles secreted by tumor cells were capable of inducing apoptosis in Fas expressing lymphocytes (54-57).

As both in vitro and in vivo, shed vesicles appear to be important vehicles for release of signaling molecules, we analyzed the effects of vesicles shed by oligodendroglioma cells on primary cultures of rat neurons. We observed that vesicles exerted an inhibitory effect on neuronal outsprouting and caused neuronal apoptosis. We therefore looked for the presence of inhibitory and proapoptotic molecules in the vesicles.

\section{Materials and methods}

Animals. Sprague-Dawley rats (Stefano Morini, San Polo d'Enza, Italy) were housed in our institutional animal care facility under direction of a licensed veterinary. Procedures involving animals were conducted according to European Community Council Directive 86/609, OJL 358 1, 12 December 1987.

Cell cultures. Neurons were prepared from fetal rat cortices at the 16th gestational day and cultured as previously described, in neuron-selective Maat medium, on laminin, at $\sim 5 \times 10^{5} \mathrm{cells} / \mathrm{cm}^{2}$ (58). G26/24 oligodendroglioma cells (59) and NIH-3T3 cells were cultured in DME-Ham's F-12 (2:1) medium supplemented with $10 \%$ fetal calf serum (FCS), and $40 \mathrm{mg}$ penicillin, $8 \mathrm{mg}$ amplicillin and $90 \mathrm{mg}$ of streptomycin per liter.

OvCa cells were cultured in DMEM medium supplemented with $10 \%$ FCS, $2 \mathrm{mM}$ glutamine and antibiotics (40 mg penicillin, $8 \mathrm{mg}$ amplicillin and $90 \mathrm{mg}$ of streptomycin per liter). Cell cultures were maintained in humidified $5 \% \quad \mathrm{CO}_{2} /$ $95 \%$ air at $37^{\circ} \mathrm{C}$.

Preparation of membrane vesicles from the cell culture medium. Vesicles were prepared as previously described in sterile conditions (37). Media conditioned by subconfluent healthy cells for $24 \mathrm{~h}$ were centrifuged at $2000 \mathrm{x}$ g for $15 \mathrm{~min}$ 
and then at $4000 \mathrm{x} \mathrm{g}$ for $15 \mathrm{~min}$. The supernatant was centrifuged at $105,000 \mathrm{x}$ g for $90 \mathrm{~min}$ at $4^{\circ} \mathrm{C}$. Pelleted vesicles were suspended with phosphate-buffered saline $\mathrm{pH} 7.5$ (PBS) and the amount of isolated vesicles was determined by measuring protein concentration by the Bradford microassay method (Bio-Rad) using bovine serum albumin (Sigma) as a standard.

Treatments of neuronal cultures. Effects of vesicles and vesiclefree conditioned medium were analyzed adding them to primary cultures of neurons plated on laminin $5 \mathrm{~h}$ previously. Vesicles released by G26/24, NIH-3T3, and OvCa cells were tested at different concentrations ( $3 \mu \mathrm{g}$ to $48 \mu \mathrm{g} / \mathrm{ml})$ and their effects were analyzed after 16 or $48-72 \mathrm{~h}$ of culture.

Neurons were treated with phosphatidylinositol-specific phospholipase C (PI-PLC) according to Fournier et al who demonstrated that this treatment solubilized $\mathrm{NgR}$ from dorsal root ganglion neurons (14). Briefly neurons were digested for 30 min with $1 \mathrm{U} / \mathrm{ml}$ of PI-PLC (Sigma); PI-PLC containing medium was removed and vesicle-free or vesicle-containing fresh medium was added.

In order to analyze the role of vesicle-associated Nogo B and Fas-L, vesicles were mixed with either $10 \mu \mathrm{g} / \mathrm{ml}$ of polyclonal antibodies against Nogo (Santa-Cruz), or $10 \mu \mathrm{g} / \mathrm{ml}$ of mouse anti Fas-L neutralizing monoclonal antibodies and incubated for $30 \mathrm{~min}$ at $37^{\circ} \mathrm{C}$, before adding them to neurons.

\section{Immunofluorescence assays}

a) Cells cultured in monolayer. All procedures were performed at room temperature. Cells were fixed with $2 \%$ paraformaldehyde in PBS for 15 min and then permeabilised by incubation with $0.1 \%$ Triton X-100 in PBS for an additional $15 \mathrm{~min}$. After rinsing, fixed cells were saturated by incubating them for $60 \mathrm{~min}$ in a wet chamber with $50 \%$ FCS and 3\% bovine serum albumin in PBS. The cells were then incubated for $60 \mathrm{~min}$ with the following primary antibodies: mouse monoclonal anti-NF, 68-kDa component, (Sigma); mouse monoclonal anti-GAP-43 (Sigma); mouse monoclonal antiMAP-2 (Sigma); goat polyclonal anti-MAG antibodies (SantaCruz), goat polyclonal anti-Nogo antibodies (Santa-Cruz), rabbit polyclonal anti-Nogo A and B Bianca antibodies (a kind gift from Dr Schwab); rabbit polyclonal anti-Fas-L antibodies (Santa-Cruz); and mouse monoclonal anti-integrin B1 C27 (60).

After rinsing, cells were further incubated for $60 \mathrm{~min}$ with secondary antibodies and rinsed again. Immunostained samples were analyzed by confocal microscopy (Olympus 1X70 with Melles Griot laser system) or by fluorescence microscopy (Olympus BX-50 microscope equipped with a Vario Cam B/W camera).

b) Cells cultured in three-dimensional type I collagen gels. Type I collagen $(500 \mu \mathrm{l})$ (Rat tail BD Biosciences, sold as a $3.9 \mathrm{mg} / \mathrm{ml}$ solution in $0.02 \mathrm{M}$ acetic acid) was mixed $\mathrm{v} / \mathrm{v}$ with cells suspended in 10\% FCS-DMEM containing $50 \mathrm{mM}$ $\mathrm{NaHCO}_{3}$ at a concentration of $\sim 300,000$ cells $/ \mathrm{ml}$, and plated, $100 \mu 1$ per well, in 96-multiwell plates (Costar 3596). As soon as gels had polymerised, $200 \mu 1$ of complete medium were added to each well. After 6 days of incubation, cells were fixed by addition of $3.7 \%$ formaldehyde (Carlo Erba) in
PBS. After rinsing, fixed cells were incubated for $2 \mathrm{~h}$ at room temperature with $1 \mu \mathrm{g} / \mathrm{ml}$ phalloidin FITC-labelled (Sigma).

Vitality assay. Cell apoptosis was observed by staining the cells with a combination of the fluorescent DNA-binding dyes, acridine orange (AO) and ethidium bromide (EB), $100 \mu \mathrm{g} / \mathrm{ml}$ in PBS for each dye (AO/EB colorimetric assay). The differential uptake of these two dyes allowed the identification of viable and non-viable cells by fluorescence microscopy. Normal nuclei in live cells appeared bright green; apoptotic nuclei in dead cells appeared bright orange with highly condensed chromatin.

Western blot analyses. Total proteins were separated by SDS-PAGE and blotted onto a nitrocellulose membrane (Hybond; Amersham Biosciences) previously saturated with $3 \%$ fat-free milk in TBS-T for $3 \mathrm{~h}$. After incubation, membranes were treated overnight with the following antibodies: mouse monoclonal anti-NF (Sigma); mouse monoclonal anti-GAP-43 (Sigma); mouse monoclonal anti-MAP-2 (Sigma); rabbit polyclonal anti-caspase-3 (Santa-Cruz); rabbit polyclonal anti-procaspase-8 (Santa-Cruz); rabbit polyclonal anti-Bcl-2 (Santa-Cruz); rabbit polyclonal anti-Fas-L (Santa-Cruz); rabbit polyclonal anti-Nogo A and B Bianca and mouse monoclonal 11C7 anti-Nogo A (kind gifts from Dr Schwab). Membranes were extensively rinsed with TBS-T and incubated for $2 \mathrm{~h}$ with secondary antibodies. Immunocomplexes were visualized with the ECL Western blot kit (Amersham Biosciences) using Hyperfilms.

\section{Results}

G26/24 oligodendroglioma cells release membrane vesicles similar to those shed by NIH-3T3 cells. As shown in Fig. 1, G26/24 cells release in their culture media vesicular structures which can be observed by phase contrast microscopy (Fig. 1a). Shed vesicles can also be easily observed when cells are cultured in three-dimensional collagen gels in which they remain trapped (Fig. 1 b and c). Vesicles shed by G26/24 cells are much larger than exosomes (the diameter of which ranges from 10 to $90 \mathrm{~nm}$ ) and are similar to or even larger than extracellular vesicles shed by several other tumor cell lines $(39,41)$. Diameters of vesicles shed by G26/24 oligodendroglioma cells (Fig. 1c) and by NIH-3T3 cells (Fig. 1d) are similar.

Vesicles were recovered from conditioned media as previously described (37). We obtained $\sim 80 \mu \mathrm{g}$ of vesicle proteins from complete media in which $\sim 20$ million subconfluent cells had been cultured for $24 \mathrm{~h}$. As described for other cell lines, FCS stimulated vesicle shedding. However, while 8701 BC and MCF-7 breast carcinoma and Sk-Hep-1 hepatocarcinoma cells cultured in serum free media do not release a measurable amount of vesicles, G26/24 oligodendroglioma cells, as well as NIH-3T3 cells, release a decreased but still measurable amount of vesicles (30 $\mu \mathrm{g}$ instead of $80 \mu \mathrm{g}$ ) also when in serum-free media.

Effects of G26/24 shed vesicles on primary fetal rat cortical neurons. Effects of vesicles shed by G26/24 cells were tested by adding them to primary cultures of neurons. Neurons were 

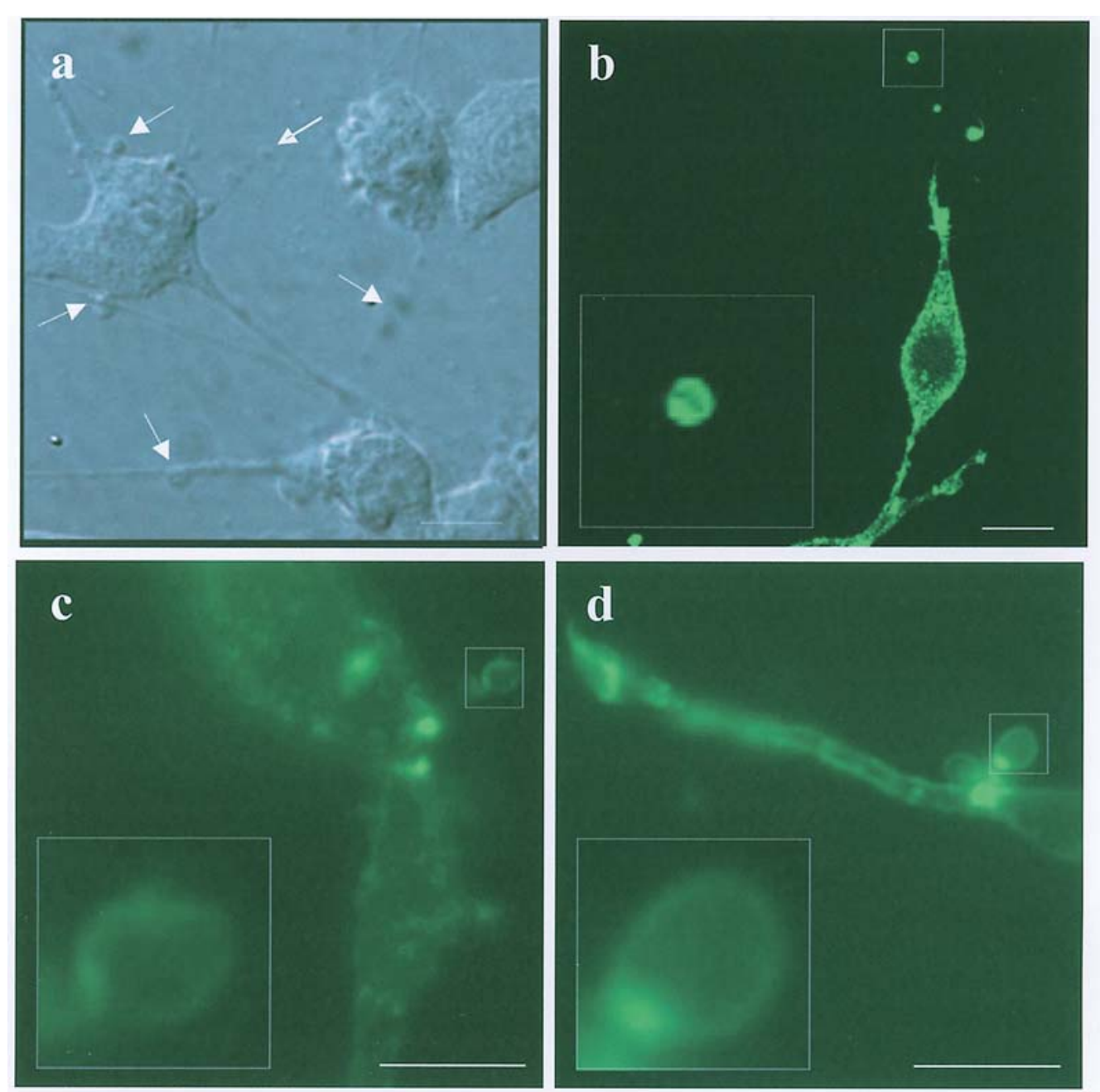

Figure 1. Vesicle shedding by G26/24 oligodendroglioma and NIH-3T3 cells. (a) Phase contrast observation of G26/24 cells. Cells were cultured in monolayers on poly-L-lysine in order to avoid vesicle dispersion. Shed vesicles are indicated by arrows. (b) Confocal observation of FITC-phalloidin labeled G26/24 oligodendroglioma cells cultured in three-dimensional collagen gels. (c) Immunofluorescence observation of FITC-phalloidin labeled G26/24 oligodendroglioma cells cultured in three-dimensional collagen gels. (d) Immunofluorescence observation of FITC-phalloidin labeled NIH-3T3 cells cultured in three-dimensional collagen gels. Bar, $10 \mu \mathrm{m}$. Squares show selected areas which are magnified (x4) in the left bottom inserts.

prepared from fetal rat cortices at the 16th gestational day and cultured on laminin as described by Cestelli et al (58). Vesicles were added to primary cultures of neurons when they had already started to produce neurites $(5 \mathrm{~h}$ after they had been plated in multiwell dishes at $\left.\sim 5 \times 10^{5} / \mathrm{cm}^{2}\right)$. Approximately $16 \mathrm{~h}$ later, an inhibitory effect of vesicles on neurite sprouting was already visible (Fig. 2A and C). After longer periods, (48-72 h) most neurons underwent apoptosis. (Fig. 2B and D). As shown in the figure, the effect was dose-dependent and already visible at a vesicle concentration of $3 \mu \mathrm{g} / \mathrm{ml}$, (i.e. the concentration of vesicles in one $\mathrm{ml}$ of G26/24 conditioned medium). In a different set of experiments, vesicles were added five days after neurons had been plated, the effects on neurite extention and cell vitality were very similar to those shown in Fig. 2. When neurons were treated with vesicle-free G26/24 oligodendroglioma conditioned media or with different concentrations of vesicles shed by NIH-3T3 cells, neither morphological nor proapoptotic effects were observed (Fig. 2A and $\mathrm{B}$, lane 7 and data not shown). When vesicles shed by G26/24 cells were tested on primary cultures of astrocytes, the cell morphology and vitality of these cells were not affected (data not shown).
Modifications of neuronal protein expression induced by vesicle treatments. As shown in Fig. 3A, Western analyses demonstrated that, after 16-h treatment with vesicles, the expression of NF p68, MAP-2 and GAP 43 was decreased; less significant differences were also observed for total actin and tubulin expression and, therefore, we standardized the Western analyses with respect to Coomassie-blue staining. Immunofluorescence analyses showed that number and extention of neurites were significantly reduced in vesicletreated cells. Distribution of neurite-associated proteins was consequently modified, with GAP-43 and MAP-2 clearly localized in the cytoplasm (Fig. 3B).

Fig. 3C shows that, after 48-72 h, induction of neuronal apoptosis was associated with a decrease in the expression level of procaspase- 3 and -8 and with an increase in the active form of caspase- 3 . The anti-procaspase- 8 polyclonal antibody we utilized for these experiments (Santa-Cruz sc-7890) does not react with the active form of caspase-8; we were therefore unable to show the increase in active caspase- 8 which is, however, suggested by the disappearance of the proenzymatic form of this enzyme. A decrease in Bcl-2 expression level was also evident. At the same time, expression of MAP-2, 
A
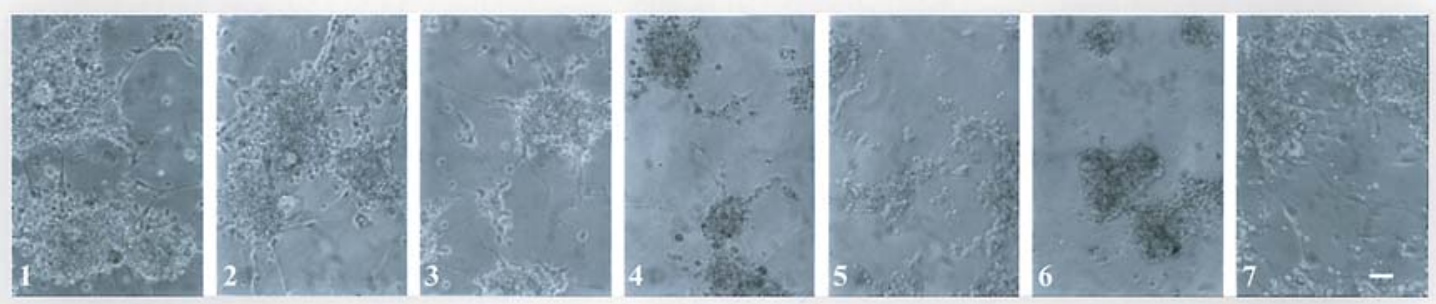

$\mathbf{B}$
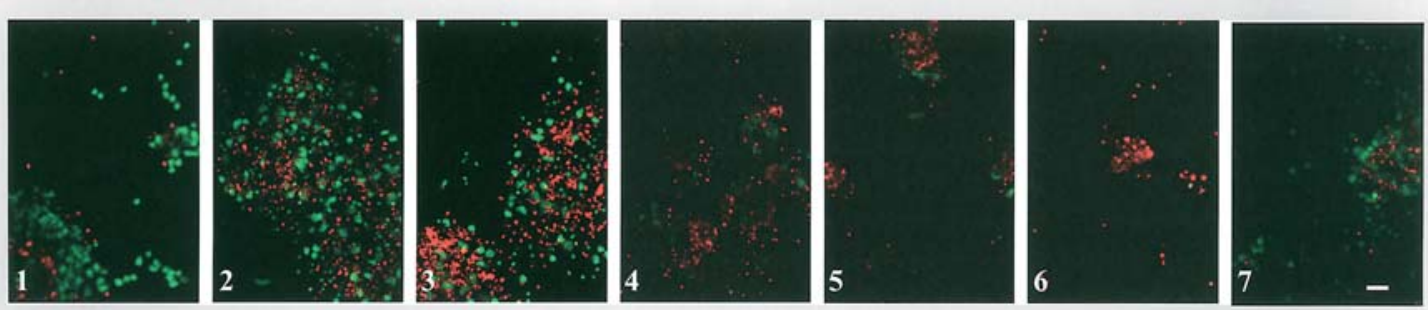

C

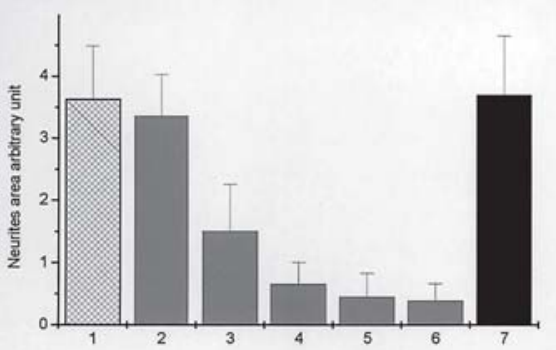

D

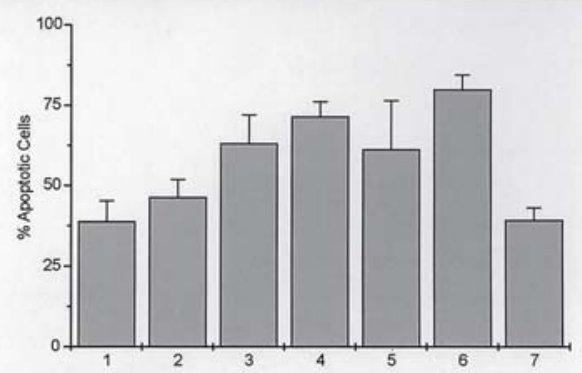

Figure 2. Dose-dependent effects of G26/24 oligodendroglioma vesicles on primary cultures of fetal rat neurons. A, phase contrast observation of neuronal cultures $16 \mathrm{~h}$ after vesicle addition. B, vitality assays of neurons by AO/EB staining, $72 \mathrm{~h}$ after vesicle addition. Normal nuclei in live cells appear bright green; apoptotic nuclei in dead cells appear bright orange with highly condensed chromatin. C, graphic representation of average neurite area, $16 \mathrm{~h}$ after vesicle addition. D, percentage of apoptotic cells $72 \mathrm{~h}$ after vesicle addition. Lane 1, neurons cultured in the absence of vesicles. Lanes 2-6, neurons cultured in the presence of 3,6, 12, $24,48 \mu \mathrm{g}$ of vesicles shed by G26/24 oligodendroglioma cells. Lane 7, neurons cultured in the presence of $40 \mu \mathrm{g}$ of vesicles shed by NIH-3T3 vesicles. Bar, $10 \mu \mathrm{m}$.

A

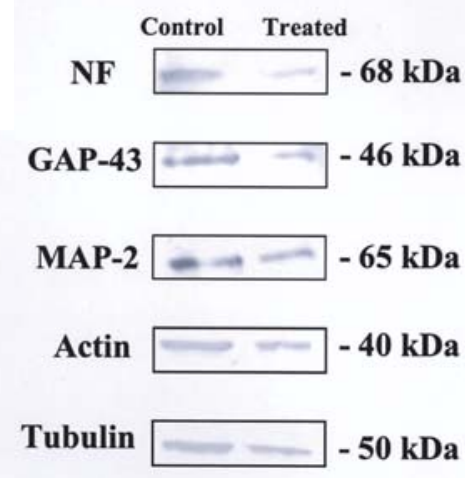

C

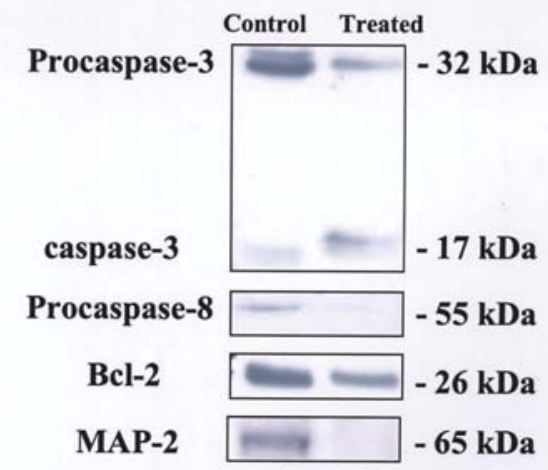

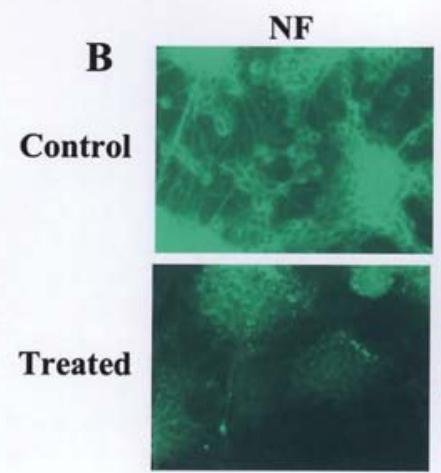
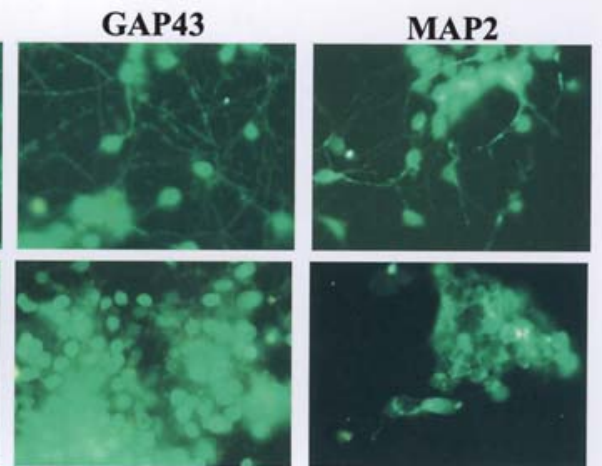

Figure 3. Modification of protein expression induced by treatment with G26/24 vesicles. Control, untreated neurons. Treated, neurons incubated with $40 \mu \mathrm{g}$ of vesicles shed by G26/24 oligodendroglioma cells. A, Western analyses after $16 \mathrm{~h}$ of incubation. B, immunofluorescence analyses after $16 \mathrm{~h}$ of incubation. Bar, $10 \mu \mathrm{m}$. C, Western analyses after $48 \mathrm{~h}$ of incubation. In A and C, sizes of identified proteins are indicated on the right margin. 
A
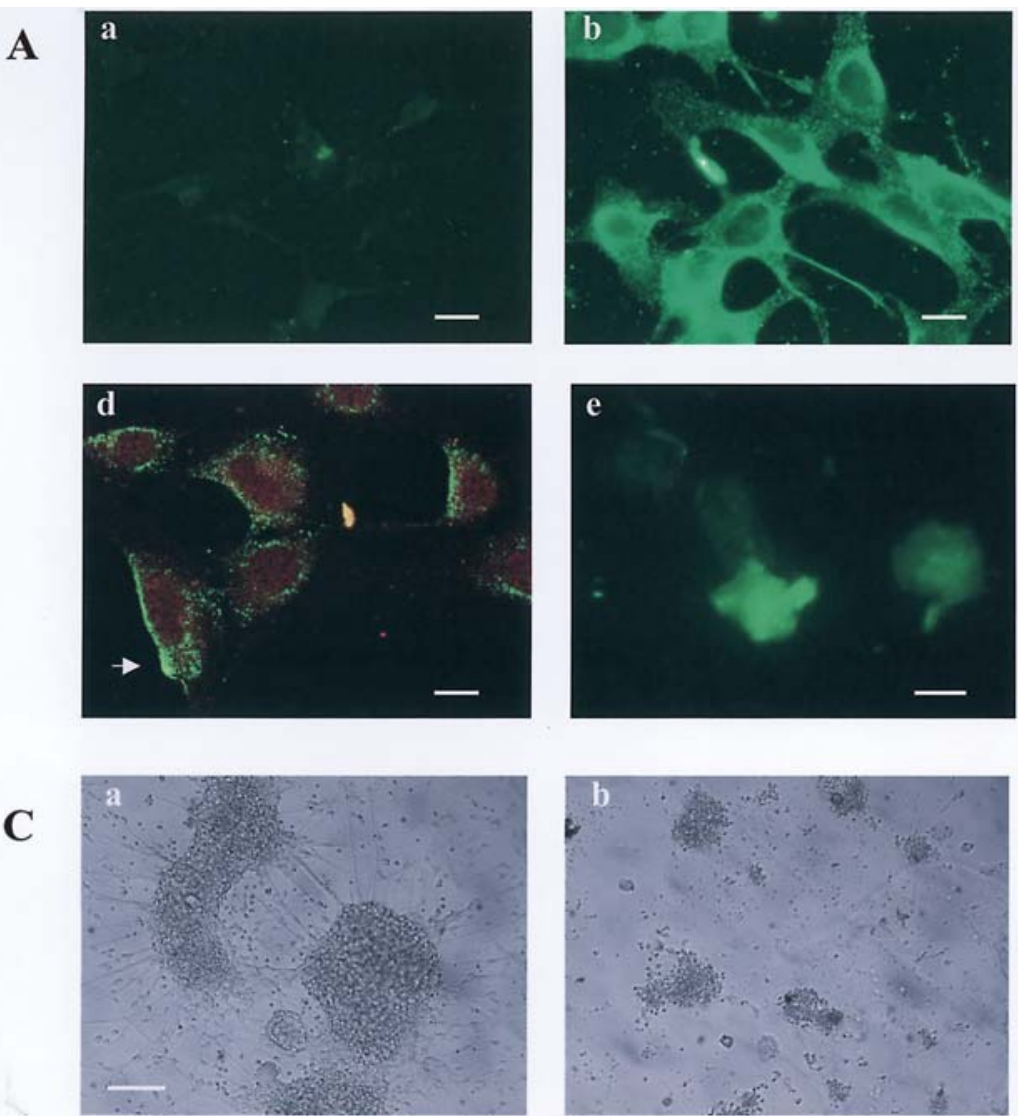

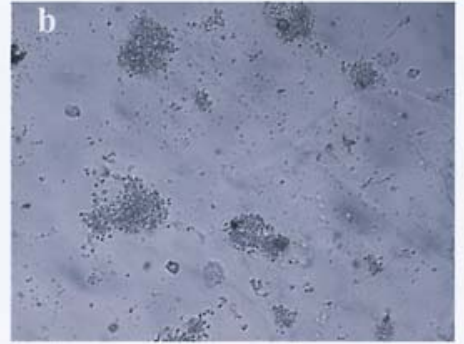

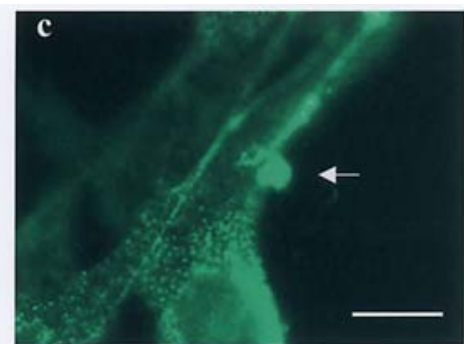

B
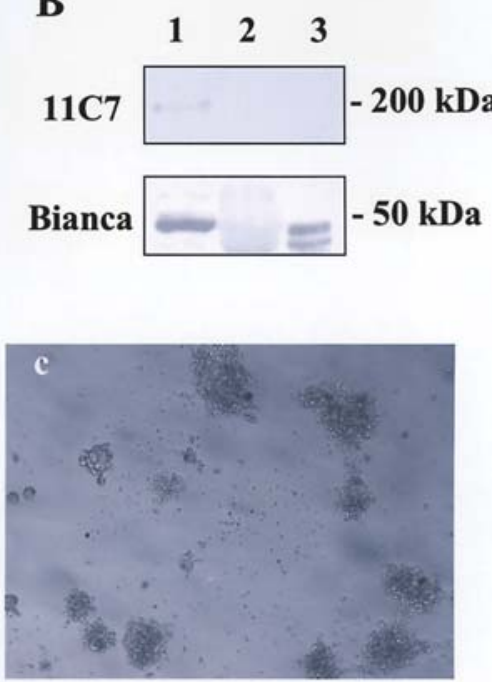

Figure 4. Involvement of myelin components in the inhibitory effect of G26/24 vesicles. A, expression of myelin inhibitory components by G26/24 oligodendroglioma cells. (a) G26/24 oligodendroglioma cells treated with anti-MAG antibodies and FITC-labeled secondary antibodies. (b) G26/24 oligodendroglioma cells treated with anti-Nogo antibodies and FITC-labeled secondary antibodies. (c) Enlargement showing that antibodies localize preferentially on sites of vesicle budding. Arrow indicates a budding vesicle. (d) Co-localization of Nogo and $\beta 1$ integrin in vesicles. Anti-Nogo antibodies were revealed by FITC-labeled secondary antibodies; anti- $\$ 1$ integrin antibodies were revealed with TRITC-labeled secondary antibodies. Arrow indicates a site of colocalization. (e) Isolated vesicles, bound to a poly-L-lysine coated cover glass, labeled by anti-Nogo antibodies. Bar, $10 \mu$ m. B, identification of the Nogo isoform(s) expressed on G26/24 shed vesicles. Western blot analyses performed with Bianca rabbit polyclonal antibodies which identifies Nogo A and Nogo B isoforms; and with 11C7 monoclonal antibody which only reacts with Nogo A. Lane 1, rat neuronal extract utilized as positive control. Lane 2, rat astrocyte extract utilized as a negative control. Lane 3, G26/24 vesicles. Sizes of reference markers are indicated on the right margin. C, effects of PIPLC digestion on the inhibitory effect of G26/24 shed vesicles. (a) Untreated neurons. (b) Neurons incubated for $16 \mathrm{~h}$ with $20 \mu \mathrm{g}$ of G26/24 vesicles. (c) Neurons which had been digested for $30 \mathrm{~min}$ with $1 \mathrm{unit} / \mathrm{ml}$ of PI-PLC (Sigma) and than incubated for $16 \mathrm{~h}$ with $20 \mu \mathrm{g}$ of G26/24 vesicles. Bar, $50 \mu \mathrm{m}$.

only slightly decreased after $16 \mathrm{~h}$ of treatment, was clearly affected.

Expression of myelin components by $G 26 / 24$ cells and shed vesicles. In an attempt to identify vesicle components responsible for the observed inhibitory and proapoptotic effects on neurons, G26/24 cells and their shed vesicles were tested for expression of myelin membrane components known for having inhibitory effects on neurons. Cells were found to be negative for MAG (Fig. 4Aa) but positive for Nogo (Fig. 4Ab). Nogo was observed to localize preferentially in specific regions of the cell plasma membrane which appear to correspond to sites of vesicle budding (Fig. 4Ac); they were in fact also specifically marked by anti- $\beta 1$ integrin antibodies (Fig. 4Ad), previously reported to be clustered in shed vesicles (38). In addition antibodies clearly labeled isolated vesicles placed on a poly-L-lysine-coated glass cover (Fig. 4Ae).

In order to identify the Nogo isoform(s) expressed in G26/24 shed vesicles, we performed Western analyses utilizing Bianca and 11C7 antibodies, a kind gift from Dr Schwab. Bianca, rabbit polyclonal antibodies recognize the protein
$\mathrm{N}$-terminal domain which is expressed both in Nogo A and Nogo B isoforms, $11 \mathrm{C} 7$ is a monoclonal antibody recognizing a specific region present exclusively in the Nogo A isoform (30). As shown in Fig. 4B, Western analyses demonstrated that the Nogo isoform present in vesicles shed by G26/24 cells is Nogo B while Nogo A is absent. As positive control, in these Western analyses, we utilized an extract of rat neurons. The slight difference in electrophoretic migration of the components marked by Bianca antibodies in neurons (from rat) and shed vesicles (from mouse oligodendroglioma cells) is probably due to the known difference in the molecular mass of Nogo B proteins in rat $(55 \mathrm{kDa})$ and mouse $(40-50 \mathrm{kDa})$ $(30,61)$.

To evaluate the role of Nogo B in the inhibitory effects of vesicles shed by G26/24 oligodendroglioma cells, before adding vesicles, neurons were treated with PI-PLC in order to solubilize the Nogo receptor $(\mathrm{NgR})$. The treatment did not affect neuronal morphology and vitality (data not shown) but the inhibitory effect of vesicles was unchanged (Fig. 4C). In a different set of experiments, anti-Nogo polyclonal antibodies (Santa-Cruz sc-11027) were added to neurons together with 
A
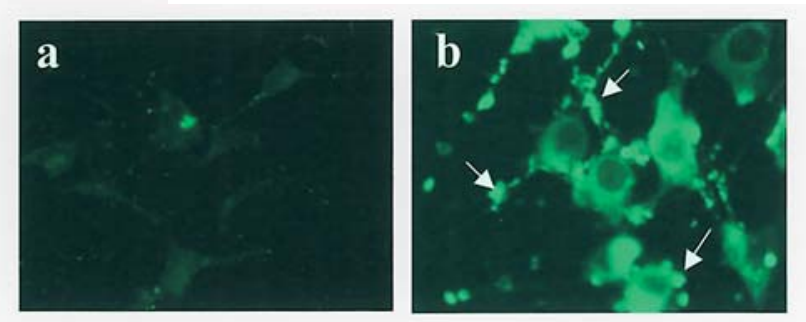

B
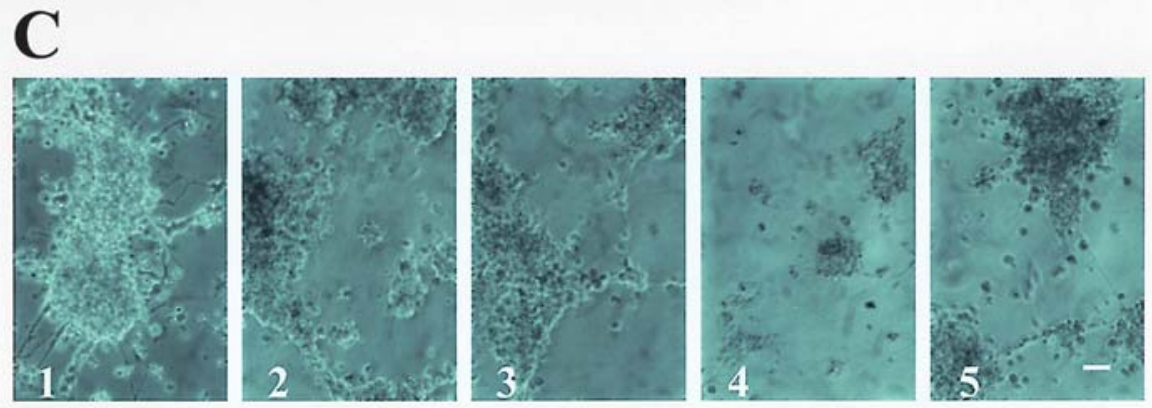

\section{D}
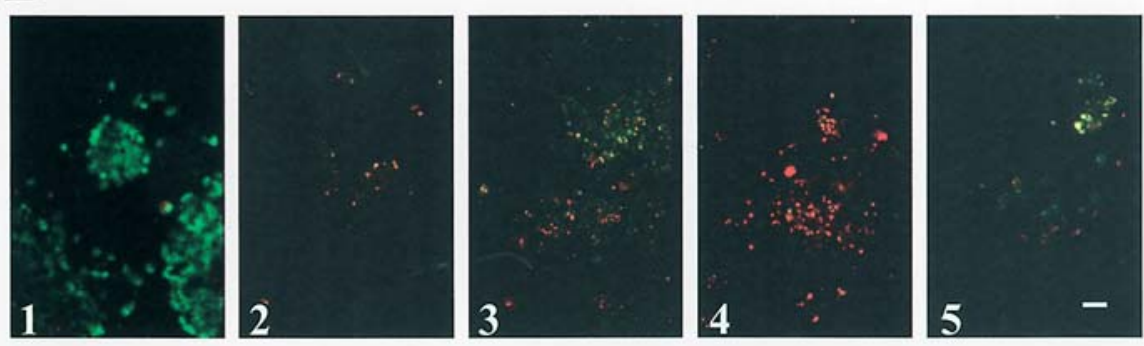

$\mathbf{E}$

$\mathbf{F}$
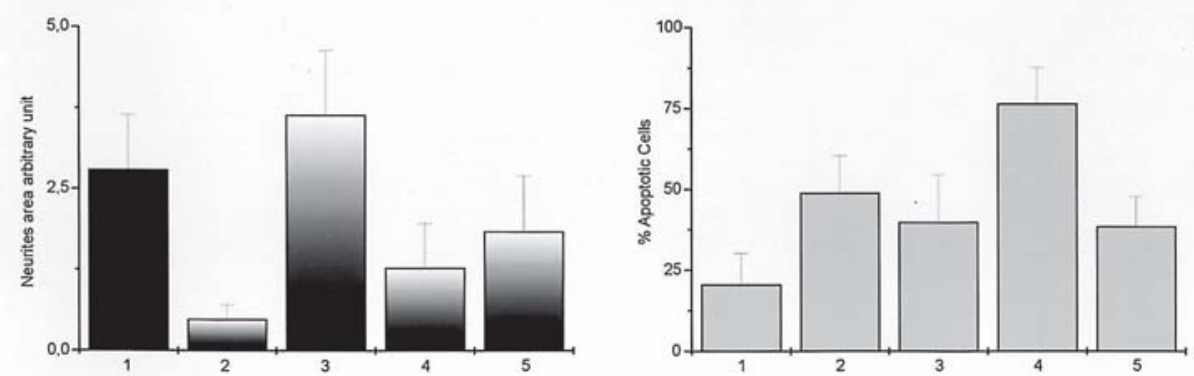

Figure 5. Involvement of Fas-Ligand in the inhibitory effect of G26/24 vesicles. A, expression of Fas-L by G26/24 oligodendroglioma cells. (a) Negative control, cells treated with secondary antibodies. (b) G26/24 oligodendroglioma cells treated with anti-Fas-L antibodies and FITC-labeled secondary antibodies. Budding vesicles are indicated by arrows. Bar, $10 \mu \mathrm{m}$. B, Western analyses of Fas-L expression in vesicles. Lane 1, vesicles shed by G26/24 oligodendroglioma cells. Lane 2, vesicles shed by OvCa ovarian carcinoma cells. C, reversion by anti-Fas-L antibodies of the inhibitory effect of vesicles on neurite extension. Phase contrast observation of neuronal cultures after $16 \mathrm{~h}$ of treatment. Bar, $10 \mu \mathrm{m}$. D, Reversion by anti-Fas-L antibodies of the inhibitory effect of vesicles on cell vitality. Assays of neuron vitality by AO/EB staining, $72 \mathrm{~h}$ of treatment. Bar, $10 \mu \mathrm{m}$. E, graphic representation of average neurite area $16 \mathrm{~h}$ of treatment. F, percentage of apoptotic cells, $72 \mathrm{~h}$ of treatment. Lane 1, neurons cultured in the absence of vesicles. Lanes 2 and 3 , neurons cultured in the presence of $20 \mu \mathrm{g}$ of G26/24 vesicles. Lanes 4 and 5, neurons cultured in the presence of $20 \mu \mathrm{g}$ of OvCa vesicles. Lanes 3 and 5 , neurons cultured in the presence of both vesicles and $10 \mu \mathrm{g} / \mathrm{ml}$ functional mouse monoclonal antibodies against Fas-L.

shed vesicles. At the maximal tested concentration $(20 \mu \mathrm{g} / \mathrm{ml})$, antibodies were unable to counteract the inhibitory effects of vesicles (data not shown).

Vesicles shed by G26/24 cells express Fas-ligand. Vesicles shed by some tumor cells are known to carry Fas-L in a biologically active form (54-57). We therefore analyzed G26/24 cells and vesicles for the presence of this molecule: both cells and vesicles were clearly positive (Fig. 5A and B). Moreover, since vesicles shed by ovarian carcinoma cells had been reported to express Fas-L, we also tested, as a reference, vesicles shed by OvCa, a stabilized human ovarian carcinoma cell line. Vesicles shed by G26/24 oligodendroglioma cells appear to express Fas-L at an even higher level compared to vesicles shed by OvCa ovarian carcinoma cells (Fig. 5B).

Functional role of Fas-L in vesicles shed by G26/24 oligodendroglioma cells. To evaluate the role of Fas-L in the 
inhibitory and proapoptotic effects vesicles shed by G26/24 oligodendroglioma cells, before adding them to neurons, vesicles were treated with functional anti-Fas-L antibodies. In order to optimize their effects, antibodies $(10 \mu \mathrm{g} / \mathrm{ml})$ were added again to the cells after $24 \mathrm{~h}$ of culture. As shown in Fig. 5C and D, antibodies largely counteracted both the inhibitory effect of vesicles on neurite outgrowth (Fig. 5C) and their proapoptotic effects $(5 \mathrm{D})$.

Since Fas-L is expressed both in vesicles shed by G26/24 and by $\mathrm{OvCa}$ cells, to analyze the role of vesicle-associated Fas-L in the inhibitory effects of vesicles on neurons, we also tested vesicles shed by OvCa cells on neuronal primary cultures. The results shown in Fig. 5C indicate that vesicles shed by these ovarian carcinoma cells are as active in inhibiting neurite sprouting and in inducing neuronal apoptosis as vesicles shed by G26/24 cells. Anti-Fas-L antibodies counteracted the effects of OvCa vesicles at levels comparable to those observed with G26/24 vesicles. Therefore, the incomplete reversion is probably due to the large amount of Fas-L expressed in vesicles shed by both cell lines. We therefore conclude that the effects of G26/24 vesicles on primary neuronal cultures are largely or exclusively due to Fas-L expression.

\section{Discussion}

Although they are slowly growing tumors, oligodendrogliomas are a frequent cause of death because they cause extensive neuronal damage. We aimed to analyze the possibility that oligodendrogliomas can induce neuronal loss by production of active molecules. We also hypothesized that the inhibitory mechanism could be mediated by shed membrane vesicles, structures which are involved in several mechanisms of cellcell and cell-matrix interactions (62).

Both hypotheses were clearly confirmed by our results. We report that oligodendroglioma cells shed membrane vesicles, and that these vesicles inhibit neurite sprouting and cause neuronal apoptosis. The inhibitory effect was not observed when vesicles shed by NIH-3T3 cells were tested.

Proapoptotic effects of vesicles were dose-dependent and observable even when $3 \mu \mathrm{g}$ of vesicles, i.e. the amount of vesicles recovered from one $\mathrm{ml}$ of $\mathrm{G} 26 / 24$ conditioned medium, was added to one $\mathrm{ml}$ of neuronal cultures. The proapoptotic effect is therefore induced also when concentrations of tumorderived vesicles are similar to those one could imagine to occur in vivo when an oligodendroglioma tumor is growing inside the central nervous system (CNS). When vesicle-free G26/24 conditioned medium was added to neurons, no inhibitory or proapoptotic effects were observed; active molecules are, therefore, associated with shed vesicles.

In an attempt to identify the vesicle-associated molecules responsible for inhibitory and proapoptotic effects on neurons, we tested G26/24 shed vesicles for the presence of myelin components with well-known negative effects on neurons. Among these molecules, MAG and Nogo A proteins were not detected. On the contrary, Nogo B was present in shed vesicles. This protein could have inhibitory effects on neurons because it includes the Nogo-66 domain which is known to interact with $\mathrm{NgR}$. In order to evaluate the role of Nogo B, we tried to neutralize Nogo signaling by removing the $\mathrm{NgR}$ from neurons by PI-PLC digestion. The treatment was without effect.
However, Western analyses indicated that, in fetal cortical neurons, $\mathrm{NgR}$ expression is extremely low, at limit of detection by standard Western blot procedures, a result which is in agreement with data reported by Mingorance et al who detected $\mathrm{NgR}$ in hippocampal neurons only in the postnatal stage (63).

Interestingly, recent reports indicate that Nogo-66 can act on neurons also by interacting with receptors different to $\mathrm{NgR}$; postnatal dorsal root ganglion or cerebellar granule neurons from mice knock-out for $\mathrm{NgR}$ were indeed still inhibited by Nogo-66 (20).

The inhibitory effects of vesicles on neurite outgrowth could, therefore, be due to Nogo B interaction with a not yet identified receptor, different from $\mathrm{NgR}$. Nevertheless, our observation that addition of anti-Nogo polyclonal antibodies does not prevent the inhibitory effect of vesicles seems to exclude Nogo B involvement in the process.

Although Nogo proteins were never reported to induce neuronal apoptosis, Nogo B is known for having proapoptotic effects in some tumor cells in which it is overexpressed (31). The inhibitory effects of Nogo proteins on neurite sprouting are considered to be due to the interactions of the plasma membrane associated Nogo proteins with the Nogo receptor, the proapoptotic effects of Nogo B in cells in which the protein is overexpressed are, however, suggested to be due to the interaction of the ER-associated molecule with cytoplasmic antiapoptotic proteins such as Bcl-2 and $\mathrm{Bcl}-\mathrm{X}_{\mathrm{L}}$, causing their sequestration (64). More recently, Qi et al reported that Nogo $\mathrm{B}$ associates with a protein of the endoplasmic reticulum (ASYIP), and that this association is probably involved in its proapoptotic effects (65).

The paracrin proapoptotic effects of G26/24 vesicles on neurons could be mediated by Nogo B induced sequestration of antiapoptotic molecules, only if the molecule were internalized by fusion of shed vesicles with the plasma membrane of the target cells. As insertion of membrane components of vesicles shed by one kind of cells into the cell membrane of a target cell has been reported, this possibility cannot be ruled out (66). Non-tumor cells were, however, reported to be less sensitive to Nogo B proapoptotic activity when compared with tumor cells (31). Moreover, the induction of apoptosis of neuronal cells by shed vesicles is associated with caspase- 8 activation, and this result points to a pro-apoptotic mechanism based on the activation of cell surface receptors. We therefore conclude that Nogo B does not play a prominent role in the proapoptotic effects caused on neurons by G26/24 shed vesicles.

Since inhibitory myelin components were not proved to be responsible for the vesicle effects, we tested vesicles shed by oligodendroglioma cells for the presence of Fas-L. This latter molecule had been identified in vesicles shed by other kinds of tumor cells. It was also reported that vesicle-bound Fas- $\mathrm{L}$ is far more active than soluble Fas- $\mathrm{L}$, and that it induces apoptosis of activated T lymphocytes (56). Our analyses demonstrated that Fas-L is indeed present in vesicles shed by G26/24 oligodendroglioma cells; moreover, functional monoclonal antibodies against Fas- $\mathrm{L}$ are able to partially revert the inhibitory effects of vesicles on neurite growth and to counteract their proapoptotic effects on neurons. Fas receptor is reported to be expressed both in neurons and astrocytes (67). The observation that vesicles shed by G26/24 oligodendroglioma cells do not affect astrocyte vitality agrees, 
however, with data showing that, in astrocytes, Fas/Fas-L interaction is not associated with astrocyte apoptosis but instead causes a response involving production of proangiogenic molecules (68-70). NIH-3T3 cells do not express a significant amount of Fas-L (data not shown) and, accordingly, NIH-3T3 do not induce neuronal apoptosis (71). Vesicles shed by ovarian carcinoma cells, which carry Fas-L, have a proapoptotic effect on neurons comparable to that of vesicles shed by oligodendroglioma cells. Also in this case, anti-Fas-L antibodies caused partial reversion of inhibitory and proapoptotic effects on neurons.

Fas-L appears, therefore, as one of the signaling molecules involved in the inhibitory and proapoptotic effects that vesicles shed by oligodendroglioma cells exert on neurons. Fas-L is known to play important roles in the brain and Fas- $\mathrm{L}$ expression in microglia is upregulated in vitro in hypoxiaischemia. In the ischemic penumbra, many cells die by apoptosis and it was found that neuronal apoptosis could be significantly reduced by Fas-L antibodies (72). However, Desbarats et al (73) and, recently, Zuliani et al (74) reported that Fas-FasL interaction does not induce apoptosis but, on the contrary, induces an increase of neuronal branching in mouse developing brain. These results are in contrast with ours. Discrepancies probably depend on differences in experimental conditions; we utilized a tumor system and, moreover, FasL associated with tumor vesicles was reported to be especially active.

The presence of Fas- $\mathrm{L}$ in vesicles shed by tumor cells is generally considered as part of the mechanism by which tumors acquire the capability to escape from host immune surveillance. The presence of the molecule in vesicles shed by oligodendrogliomas appears to have an additional meaning in allowing production of a cell-free environment in which tumor cells can grow. The brain is an immune-privileged organ in which immune response is decreased by the absence of lymphatic vases and by the presence of the blood-brain barrier; it is, however, a narrow place, delimited by bones and other barriers, in which tumors would be unable to grow unless the space in which cells are growing is obtained by killing surrounding cells.

The present results indicate once more that shed vesicles play a very important role in cell-cell interactions and that they are specifically involved in several tumor progression mechanisms.

\section{Acknowledgments}

This work was supported by grants from the Italian Association for Cancer Research and by the Italian Ministry of University and Research (MIUR, PRIN) to M.L. Vittorelli. S. D'Agostino was also supported by a grant from Palermo University to young researchers. We are grateful to M.E. Schwab and D. Dodd for kindly providing us with different anti-Nogo antibodies and for hosting Stefania D'Agostino in their lab and to G. Ghersi for his help in performing statistical analyses of data. We dedicate this report to Alessandro Cestelli who actively contributed to starting this research but didn't have enough time to live and see its developments: we still miss his special combination of knowledge, enthusiasm and humor.

\section{References}

1. Lantos PL and Pilkington GJ: Neuronal changes in experimental gliomas. Neuropathol Appl Neurobiol 6: 255-266, 1980.

2. Subramanian A, Harris A, Piggott K, Shieff C and Bradford R: Metastasis to and from the central nervous system-the 'relatively protected site'. Lancet Oncol 3: 498-507, 2002.

3. Sontheimer H: Malignant gliomas: perverting glutamate and ion homeostasis for selective advantage. Trends Neurosci 265: 43-49, 2003.

4. Kintage GJ, Templeton KL and Jenkins RB: Recent advances in the molecular genetics of primary gliomas. Curr Opin Oncol 15: 197-203, 2003.

5. Thom M: Neuropathological findings in epilepsy. Curr Diagn Pathol 10: 93-105, 2004.

6. Schaller B and Ruegg S: Brain tumor and seizures: pathophysiology and its implications for treatment revisited. Epilepsia 44: 1223-1232, 2003.

7. Goel S, Wharton SB, Brett LP and Whittle IR: Morphological changes and stress responses in neurons in cerebral cortex infiltrated by diffuse astrocytoma. Neuropathology 23: 262-270, 2003.

8. Horner PJ and Gage FH: Regenerating the damaged central nervous system. Nature 407: 963-970, 2000.

9. Schwab ME and Thoenen H: Dissociated neurons regenerate into sciatic but not optic nerve explants in culture irrespective of neurotrophic factors. J Neurosci 5: 2415-2423, 1985.

10. Ng WP, Cartel N, Roder J, Roach A and Lozano A: Human central nervous system myelin inhibits neurite outgrowth. Brain Res 720: 17-24, 1996.

11. Fawcett JW and Geller HM: Regeneration in the CNS: optimism mounts. Trends Neurosci 21: 179-180, 1998.

12. Qiu J, Cai D and Filbin MT: Glial inhibition of nerve regeneration in the mature mammalian CNS. Glia 29: 166-174, 2000.

13. Sandvig A, Berry M, Barrett LB, Butt A and Logan A: Myelin-, reactive glia-, and scar-derived CNS axon growth inhibitors: expression, receptor signalling, and correlation with axon regeneration. Glia 46: 225-251, 2004.

14. Fournier AE, GrandPré T and Strittmatter SM: Identification of a receptor mediating Nogo-66 inhibition of axonal regeneration. Nature 409: 341-346, 2001

15. Liu BP, Fournier A, GrandPre T and Strittmatter SM: Myelinassociated glycoprotein as a functional ligand for the Nogo-66 receptor. Science 297: 1190-1193, 2002.

16. Wang KC, Kim JA, Sivasankaran R, Segal R and He Z: P75 interacts with the Nogo receptor as a co-receptor for Nogo, MAG and OMgp. Nature 420: 74-78, 2002.

17. Mi S, Lee X, Shao Z, Thill G, Ji B, Relton J, Levesque M, Allaire N, Perrin S, Sands B, Crowell T, Cate RL, McCoy JM and Pepinsky RB: LINGO-1 is a component of the Nogo-66 receptor/p75 signaling complex. Nat Neurosci 7: 221-228, 2004.

18. Shao Z, Browning JL, Lee X, Scott ML, Shulga-Morskaya S, Allaire N, Thill G, Levesque M, Sah D, McCoy JM, Murray B, Jung V, Pepinsky RB and Mi S: TAJ/TROY, an orphan TNF receptor family member, binds Nogo-66 receptor 1 and regulates axonal regeneration. Neuron 45: 353-359, 2005.

19. Park JB, Yiu G, Kaneko S, Wang J, Chang J, He XL, Garcia KC and He Z: A TNF receptor family member, TROY, is a coreceptor with Nogo receptor in mediating the inhibitory activity of myelin inhibitors. Neuron 45: 345-351, 2005.

20. Zheng B, Atwal J, Ho C, Case L, He XL, Garcia KC, Steward O and Tessier-Lavigne M: Genetic deletion of the Nogo receptor does not reduce neurite inhibition in vitro or promote corticospinal tract regeneration in vivo. Proc Natl Acad Sci USA 102: 1205-1210, 2005.

21. McKerracher L, David S, Jackson DL, Kottis V, Dunn RJ and Braun PE: Identification of myelin-associated glycoprotein as a major myelin-derived inhibitor of neurite growth. Neuron 13: 805-811, 1994.

22. Mukhopadhyay G, Doherty P, Walsh FS, Crocker PR and Filbin MT: A novel role for myelin-associated glycoprotein as an inhibitor of axonal regeneration. Neuron 13: 757-767, 1994.

23. Bartsch L, Bandtlow CE, Schnell L, Bartsch S, Spillmann AA, Rubin BP, Hillenbrand R, Montag D, Schwab ME and Schachner M: Lack of evidence that the myelin-associated glycoprotein is a major inhibitor of axonal regeneration in the CNS: Neuron 15: 1375-1381, 1995. 
24. Tang S, Qui J, Nikulina E and Filbin MT: Soluble myelinassociated glycoprotein released from damaged white matter inhibits axonal regeneration. Mol Cell Neurosci 18: 259-269, 2001.

25. Chen MS, Huber AB, van der Haar ME, Frank M, Schnell L, Spillmann AA, Christ F and Schwab ME: Nogo-A is a myelinassociated neurite outgrowth inhibitor and an antigen for monoclonal antibody IN-1. Nature 403: 434-439, 2000.

26. GrandPrè T, Nakamura F, Vartanian T and Strittmatter SS: Identification of the Nogo inhibitor of axon regeneration as a Reticulon protein. Nature 403: 439-444, 2000.

27. Prinjha R, Moore SE, Vinson M, Blake S, Morrow R, Christie G, Michalovich D, Simmons DL and Walsh FS: Inhibitor of neurite outgrowth in humans. Nature 403: 383-384, 2000.

28. Dodd DA, Niederoest B, Bloechlinger S, Dupuis L, Loeffler JP and Schwab ME: Nogo-A, $-\mathrm{B}$, and $-\mathrm{C}$ are found on the cell surface and interact together in many different cell types. J Biol Chem 280: 12494-12502, 2005.

29. Kim J-E, Bonilla IE, Qiu D and Strittmatter SM: Nogo-C is sufficient to delay nerve regeneration. Mol Cell Neurosci 23: 451-459, 2003.

30. Huber AB, Weinmann O, Brosamle C, Oertle T and Schwab ME: Patterns of Nogo mRNA and protein expression in the developing and adult rat and after CNS lesion. J Neurosci 22: 3553-3567, 2002.

31. Li Q, Qi B, Oka K, Shimakage M, Yoshioka N, Inoue H, Hakura A, Kodama K, Stanbridge EJ and Yutsudo M: Link of a new type of apoptosis-inducing gene ASY/NogoB to human cancer. Oncogene 20: 3929-3936, 2001

32. Kottis V, Thibault P, Mikol D, Xiao ZC, Zhang R, Dergham P and Braun PE: Oligodendrocyte-myelin glycoprotein (OMgp) is an inhibitor of neurite outgrowth. J Neurochem 82: 1566-1569, 2002.

33. Wang KC, Koprivica V, Kim JA, Sivasankaran R, Guo Y, Neve RL and He Z: Oligodendrocyte-myelin glycoprotein is a Nogo receptor ligand that inhibits neurite outgrowth. Nature 417: 941-944, 2002.

34. Vourc'h P and Andres C: Oligodendrocyte myelin glycoprotein (OMgp): evolution, structure and function. Brain Res Rev 45: 115-124, 2004.

35. Caroni P and Schwab ME: Two membrane protein fractions from rat central myelin with inhibitory properties for neurite growth and fibroblast spreading. J Cell Biol 106: 1281-1288, 1988.

36. Dainiak N: Surface membrane-associated regulation of cell assembly, differentiation, and growth. Blood 78: 264-276, 1991.

37. Dolo V, Ginestra A, Ghersi G, Nagase H and Vittorelli ML: Human breast carcinoma cells cultured in the presence of serum shed membrane vesicles rich in gelatinolytic activities. J Submicrosc Cytol Pathol 26: 173-180, 1994.

38. Dainiak N and Sorba S: Intracellular regulation of the production and release of human erythroid-directed lymphokines. J Clin Invest 87: 213-220, 1991.

39. Taverna S, Ghersi G, Ginestra A, Rigogliuso S, Pecorella S, Alaimo G, Saladino F, Dolo V, Dell'Era P, Pavan A, Pizzolanti G, Mignatti P, Presta M and Vittorelli ML: Shedding of membrane vesicles mediates fibroblast growth factor-2 release from cells. J Biol Chem 278: 51911-51919, 2003.

40. Dolo V, Adobati E, Canevari S, Picone MA and Vittorelli ML: Membrane vesicles shed into the extracellular medium by human breast carcinoma cells carry tumor-associated surface antigens. Clin Exp Metastasis 13: 277-286, 1995.

41. Dolo V, Ginestra A, Cassarà D, Violini S, Lucania G, Torrisi MR, Nagase H, Canevari S, Pavan A and Vittorelli ML: Selective localization of matrix metalloproteinase 9 , beta1 integrins, and human lymphocyte antigen class I molecules on membrane vesicles shed by $8701-B C$ breast carcinoma cells. Cancer Res 58: 4468-4474, 1998

42. Trams EG, Lauter CJ, Salem N Jr and Heine U: Exfoliation of membrane ecto-enzymes in the form of micro-vesicles. Biochem Biophys Acta 645: 63-70, 1981.

43. Heijnen HF, Schiel AE, Fijnheer R, Geuze HJ and Sixma JJ: Activated platelets release two types of membrane vesicles: microvesicles by surface shedding and exosomes derived from exocytosis of multivesicular bodies and alpha-granules. Blood 94: 3791-3799, 1999.

44. Cooper DN and Barondes SH: Evidence for export of a muscle lectin from cytosol to extracellular matrix and for a novel secretory mechanism. J Cell Biol 110: 1681-1691, 1990.
45. Guha A, Tuck D, Sorba S and Dainiak N: Expression of membrane-bound burst-promoting activity is mediated by allogeneic effector cells. Exp Hematol 21: 1335-1341, 1993.

46. Tuck DP, Cerretti DP, Hand A, Guha A, Sorba S and Dainiak N: Human macrophage colony-stimulating factor is expressed at and shed from the cell surface. Blood 84: 2182-2188, 1994.

47. D'Angelo M, Billings PC, Pacifici M, Leboy PS and Kirsch T: Authentic matrix vesicles contain active metalloproteases (MMP). A role for matrix vesicle-associated MMP-13 in activation of transforming growth factor-beta. J Biol Chem 276: 11347-11353, 2001.

48. MacKenzie A, Wilson HL, Kiss-Toth E, Dower SK, North RA and Surprenant A: Rapid secretion of interleukin-1beta by microvesicle shedding. Immunity 15: 825-835, 2001.

49. Poste G and Nicolson GL: Arrest and metastasis of blood-borne tumor cells are modified by fusion of plasma membrane vesicles from highly metastatic cells. Proc Natl Acad Sci USA 77: 399-403, 1980.

50. Zucker S, Wieman JM, Lysik RM, Wilkie DP, Ramamurthy N and Lane B: Metastatic mouse melanoma cells release collagengelatin degrading metalloproteinases as components of shed membrane vesicles. Biochim Biophys Acta 924: 225-237, 1987.

51. Ginestra A, Monea S, Seghezzi G, Dolo V, Nagase H, Mignatti $\mathrm{P}$ and Vittorelli ML: Urokinase plasminogen activator and gelatinases are associated with membrane vesicles shed by human HT1080 fibrosarcoma cells. J Biol Chem 272: 17216-17222, 1997.

52. Ginestra A, La Placa MD, Saladino F, Cassarà D, Nagase H and Vittorelli ML: The amount and proteolytic content of vesicles shed by human cancer cell lines correlates with their in vitro invasiveness. Anticancer Res 18: 3433-3437, 1998.

53. Sidhu SS, Mengistab AT, Tauscher AN, La Vail J and Basbaum C: The microvesicle as a vehicle for EMMPRIN in tumor-stromal interactions. Oncogene 23: 956-963, 2004.

54. Albanese J, Meterissian S, Kontogiannea M, Dubreuil C, Hand A, Sorba $S$ and Dainiak N: Biologically active Fas antigen and its cognate ligand are expressed on plasma membrane-derived extracellular vesicles. Blood 91: 3862-3874, 1998.

55. Abrahams VM, Straszewski SL, Kamsteeg M, Hanczaruk B and Schwartz PE: Epithelial ovarian cancer cells secrete functional Fas ligand. Cancer Res 63: 5573-5581, 2003.

56. Andreola G, Rivoltini L, Castelli C, Huber V, Perego P, Deho P, Squarcina P, Accornero P, Lozupone F, Lugini L, Stringaro A, Molinari A, Arancia G, Gentile M, Parmiani G and Fais S: Induction of lymphocyte apoptosis by tumor cell secretion of FasL-bearing microvesicles. J Exp Med 195: 1303-1316, 2002.

57. Martinez-Lorenzo MJ, Anel A, Alava MA, Pineiro A, Naval J, Lasierra P and Larrad L: The human melanoma cell line MelJuSo secretes bioactive FasL and APO2L/TRAIL on the surface of microvesicles. Possible contribution to tumor counterattack. Exp Cell Res 295: 315-329, 2004.

58. Cestelli A, Savettieri G, Ferraro D and Vitale F: Formulation of a novel synthetic medium for selectively culturing rat CNS neurons. Brain Res 354: 219-227, 1985.

59. Sundarraj N, Schachner M and Pfeiffer SE: Biochemically differentiated mouse glial lines carrying a nervous specific cell surface antigen (NS-1). Proc Natl Acad Sci USA 72: 1927-1931, 1975.

60. Mueller SC, Ghersi G, Akiyama SK, Sang Q-X A, Howard L, Pineiro-Sanchez ML, Nakahara H, Yeh Y and Chen W-T: A novel protease-docking function of integrin at invadopodia. J Biol Chem 274: 24947-24952, 1999.

61. Magnusson C, Libelius R and Tagerud S: Nogo (Reticulon 4) expression in innervated and denervated mouse skeletal muscle. Mol Cell Neurosci 22: 298-307, 2003.

62. Vittorelli ML: Shed membrane vesicles and clustering of membrane-bound proteolytic enzymes. In: Cell Surface Proteases. Zucker S and Chen W-T (eds). Curr Top Dev Biol 54: 411-432, 2003.

63. Mingorance A, Fontana X, Sole M, Burgaya F, Urena JM, Teng FYH, Tang BL, Hunt D, Anderson PN, Bethea JR, Schwab ME, Soriano E and del Rio JA: Regulation of Nogo and Nogo receptor during the development of the entorhinohippocampal pathway and after adult hippocampal lesions. Mol Cell Neurosci 26: 34-49, 2004.

64. Tagami E, Eguchi Y, Kinoshita M, Takeda M and Tsujimoto Y: A novel protein, RTN-Xs, interacts with both Bcl- $\mathrm{X}_{\mathrm{L}}$ and $\mathrm{Bcl}-2$ on endoplasmic reticulum and reduces their anti-apoptotic activity. Oncogene 19: 5736-5746, 2000. 
65. Qi B, Qi Y, Watari A, Yoshioka N, Inoue H, Minemoto Y, Yamashita K, Sasagawa T and Yutsudo M: Pro-apoptotic ASY/ Nogo-B protein associates with ASYIP. J Cell Physiol 196: 312-318, 1993.

66. Janowska-Wieczorek A, Wysoczynski M, Kijowski J, MarquezCurtis L, Machalinski B, Ratajczak J and Ratajczak MZ: Microvesicles derived from activated platelets induce metastasis and angiogenesis in lung cancer. Int J Cancer 113: 752-760, 2005.

67. Choi $\mathrm{C}$ and Benveniste EN: Fas ligand/Fas system in the brain: regulator of immune and apoptotic responses. Brain Res Rev 44: 65-81, 2004.

68. Shinohara H, Yagita H, Ikawa Y and Oyaizu N: Fas drives cell cycle progression in glioma cells via extracellular signal-regulated kinase activation. Cancer Res 60: 1766-1772, 2000.

69. Wosik K, Becher B, Ezman A, Nalbantoglu J and Antel J. Caspase- 8 expression and signalling in Fas injury-resistant human fetal astrocytes. Glia 33: 217-224, 2001.
70. Saas P, Walker PR, Quiquerez AL, Chalmers DE, Arrighi JF, Lienard A, Boucraut J and Dietrich PY: A self-defence mechanism of astrocytes against Fas-mediated death involving interleukin-8 and CXCR2. Neuroreport 13: 1921-1924, 2002.

71. Azzaroli F, Mehal W, Soroka CJ, Wang L, Lee J, Crispe N and Boyer JL: Ursodeoxycholic acid diminishes Fas-ligand-induced apoptosis in mouse hepatocytes. Hepatology 36: 49-54, 2002.

72. Mehmet H: Stroke treatment enters the Fas lane. Cell Death Differ 8: 659-661, 2001.

73. Desbarats J, Birge RB, Mimouni-Rongy M, Weinstein DE, Palerme JS and Newell MK: Fas engagement induces neurite growth through ERK activation and p35 upregulation. Nat Cell Biol 2: 118-125, 2003.

74. Zuliani C, Kleber S, Klussmann S, Wenger T, Kenzelmann M, Schreglmann N, Martinez A, Del Rio JA, Soriano E, Vodrazka P, Kuner R, Groene HJ, Herr I, Krammer PH and Martin-Villalba A: Control of neuronal branching by the death receptor CD95 (Fas/Apo-1). Cell Death Differ 13: 31-40, 2006. 